\title{
Evaluation of the Antidiabetic Activity of Alchemilla persica Rothm. in Mice with Diabetes Induced by Alloxan
}

\author{
Alloksanla İndüklenen Farelerde Alchemilla persica Rothm.'nın \\ Antidiyabetik Etkisinin Değerlendirilmesi
}

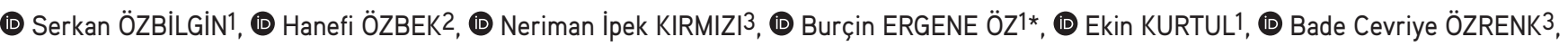 \\ (D) Gülçin SALTAN IŞCAN1', (D) Özlem BAHADIR ACIKARA ${ }^{1}$ \\ 1Ankara University, Faculty of Pharmacy, Department of Pharmacognosy, Ankara, Turkey \\ 2istanbul Medipol University, Faculty of Medicine, Department of Pharmacology, İstanbul, Turkey \\ 3istanbul Medipol University, Faculty of Medicine, Department of Vocational School of Health Services, İstanbul, Turkey
}

\section{ABSTRACT}

Objectives: Alchemilla species are used in Turkish folk medicine for the treatment of many diseases together with diabetes. Alchemilla persica, belonging to this genus, is widely distributed in Eastern Anatolia as well as in Caucasia, northern and northeastern Iran, and northern Iraq.

Materials and Methods: Methanolic-water extracts of the aerial parts and roots of $A$. persica were evaluated for their hypoglycemic activities in mice with alloxan-induced diabetes in order to verify its usage in folk medicine.

Results: None of the tested extracts exhibited a significant lowering effect on blood glucose levels. However, the aerial parts notably increased blood glucose levels at doses of $100 \mathrm{mg} / \mathrm{kg}$ and $200 \mathrm{mg} / \mathrm{kg}$.

Conclusion: A. persica usage as an antidiabetic is not confirmed in the present study.

Key words: Alchemilla persica, alloxan, antidiabetic activity, diabetes, hypoglycemic activity

öz

Amaç: Alchemilla türleri Türk halk tıbbında diyabetin yanında birçok hastalı̆ıın da tedavisinde kullanılmaktadır. Bu cinse ait olan Alchemilla persica; Doğu Anadolu, Kafkasya, Kuzey ve Kuzeydoğu İran ile Kuzey Irak'ta yetişmektedir.

Gereç ve Yöntemler: Bu çalışmada Alchemilla persica'nın halk arasındaki kullanımını doğrulamak amacıyla; toprak üstü kısım ve köklerinin sulumetanollü ekstrelerinin alloksan indüklü diyabetik fareler üzerindeki hipoglisemik etkileri test edilmiștir.

Bulgular: Test edilen ekstrelerden hiçbiri kan glukoz düzeyini kayda değer biçimde düşürmezken, $A$. persica toprak üstü kısımları kan glukoz düzeyini $100 \mathrm{mg} / \mathrm{kg}$ ve $200 \mathrm{mg} / \mathrm{kg}$ dozlarda önemli ölçüde artırmıştır.

Sonuç: Bu çalışma A. persica'nın antidiyabetik olarak kullanımını doğrulamamıştır.

Anahtar kelimeler: Alchemilla persica, alloksan, antidiyabetik aktivite, diyabet, hipoglisemik aktivite

*Correspondence: E-mail: ergene@pharmacy.ankara.edu.tr, Phone: +90 5426886226 ORCID-ID: orcid.org/0000-0001-6927-6652

Received: 09.02.2018, Accepted: 16.05.2018

-Turk J Pharm Sci, Published by Galenos Publishing House. 


\section{INTRODUCTION}

The genus Alchemilla L. (Rosaceae), with more than 1000 species, is distributed mainly in western Eurasia as well as in southern and eastern Africa, Madagascar, southern India, Sri Lanka, and Java.1.2 In Turkey 50 species of the genus Alchemilla, which are mainly distributed in Northeast Anatolia, were recorded and this number has reached 74 with new records.' Alchemilla persica Rothm., belonging to this genus, grows naturally in Eastern Anatolia, Caucasia, northern and northeastern Iran, and northern Iraq. ${ }^{3}$

Alchemilla vulgaris L. (lady's mantle, bear's foot, lion's foot) is the best known species from the genus Alchemilla and is mainly used for treating women's illnesses, wounds, and skin disorders in Europe. . $^{4-6}$ Its usage for nonspecific diarrhea is approved by Commission E. ${ }^{7}$ Additionally, ESCOP Monographs described this plant's usage for nonspecific diarrhea, gastrointestinal disorders, and dysmenorrhea based on clinical studies and long-term use. ${ }^{8}$ Alchemilla species are used for their wound healing, sedative, ${ }^{9-12}$ antidiareic, tonic, and diuretic activities, ${ }^{13-15}$ and in treatment for menstruation disorders, ${ }^{16}$ gynecological problems, ${ }^{17,18}$ liver inflammation, ${ }^{17}$ asthma, bronchitis, cough, ${ }^{19}$ and diabetes, as well as kidney, intestinal, and gastric disorders ${ }^{20-21}$ and skin diseases. ${ }^{10}$

Previous studies have revealed that the aerial parts and roots of $A$. persica showed antioxidant activity by DPPH radical scavenging ( $\mathrm{IC}_{50} 0.055 \mathrm{M}$ and $0.151 \mathrm{M}$, respectively) and reducing MDA levels $(5.9 \mathrm{nmol} / \mathrm{mL}$ and $19.08 \mathrm{nmol} / \mathrm{mL}$ respectively).22 Extract of the aerial parts of $A$. persica exhibited a reduction in the endometrioma. However, no significant reduction in the levels of cytokine, tumor necrosis factor- $\alpha$, vascular endothelial growth factor, or interleukin-6 were recorded. ${ }^{23} A$. persica displayed significant wound healing activity with tensile strength values of $33.3 \%$ and contraction values of $43.5 \%$ in linear incision and circular excision wound models, respectively. Hydroxyproline estimation and histopathological analysis also confirmed the results. A. persica showed significant anti-inflammatory activity with a value of $26.6 \% .{ }^{24}$ Phenolic constituents, namely caffeic acid esters with sugars, flavonoid glycosides, catechin and epicatechin, condensed tannins related to gallic acid, such as pedunculatin/pedunculagin, agrimoniin, casuarictin, castalagin/vescalagin, and sanguiin $\mathrm{H}-10$ isomers, were identified by HR-MS Q-TOF in the aerial parts of $A$. persica and its essential oil consisted of diterpenoids (19.6\%) and sesquiterpenoids (17.2\%) mainly. ${ }^{25}$

The current study was designed to evaluate the hypoglycemic activities of the roots and aerial parts of $A$. persica using an alloxan-induced diabetic mice test model to test its traditional usage for treatment of diabetes in Turkish folk medicine.

\section{MATERIALS AND METHODS}

\section{Plant material}

Plant material was collected from the Kop Pass, Erzurum, Turkey. The taxonomic identification of these plants was confirmed by H. Duman, at the Department of Biological Sciences, Faculty of Arts and Sciences, Gazi University. Voucher specimens were deposited in the herbarium of the Faculty of Pharmacy at Ankara University (AEF 25896).

\section{Extraction}

Aerial parts and roots of $A$. persica were extracted with a methanol:water (80:20) solvent system for $8 \mathrm{~h}$ at room temperature by stirring and then filtered. The methanol was evaporated under vacuum at $35-40^{\circ} \mathrm{C}$ and then the remaining water was lyophilized to obtain crude extracts.

\section{Animals}

Balb/C mice (22-30 g) were used for testing antidiabetic activity. The study protocol (30/09/2015-69) was approved by the Ethical Committee of İstanbul Medipol University. The animals were housed in standard cages $(48 \mathrm{~cm} \times 35 \mathrm{~cm} \times 22 \mathrm{~cm}$ ) at room temperature $\left(22 \pm 2^{\circ} \mathrm{C}\right)$, with artificial light from $7.00 \mathrm{am}$ to $7.00 \mathrm{pm}$, and provided with pelleted food and water ad libitum. The procedures followed were in accordance with animal rights as per the Guide for the Care and Use of Laboratory Animals.

\section{Chemicals}

Alloxan was purchased from Sigma (Steinheim, Germany). The alloxan and $A$. persica extracts were dissolved in distilled water $(\mathrm{w} / \mathrm{v})$.

\section{Antidiabetic activity}

Diabetes was induced by injecting $150 \mathrm{mg} / \mathrm{kg}$ of alloxan solution in isotonic saline solution (ISS) i.p. into the mice after fasting for $18 \mathrm{~h}$. This procedure was repeated three times at 48 $\mathrm{h}$ intervals. After 7 days of treatment, the mice's blood glucose levels were measured. The mice with $200 \mathrm{mg} / \mathrm{dL}$ or over were included in the study as diabetic mice. The diabetic animals were randomly divided into five groups of six animals each. Group I mice received $0.1 \mathrm{~mL}$ of ISS i.p. The animals in groups II and III were treated with $100 \mathrm{mg} / \mathrm{kg}$ body weight of extracts of the aerial parts of A. persica at $100 \mathrm{mg} / \mathrm{kg}$ and $200 \mathrm{mg} / \mathrm{kg}$ doses, while those in groups IV and V were treated with 100 $\mathrm{mg} / \mathrm{kg}$ and $200 \mathrm{mg} / \mathrm{kg}$ root extract of $A$. persica, respectively. The animals were treated with ISS and $A$. persica extracts in a single dose at the beginning of the procedure. Blood was taken from the tail vein by scalpel blade and blood glucose levels were determined before treatment and 1,2 , and $4 \mathrm{~h}$ after treatment by applying the glucose oxidase peroxidase method using an Accu-Check ${ }^{\circledR}$ device (Abbott, United Kingdom).

\section{Statistical analysis}

The statistics were analyzed using SPSS 18.0. The results are reported as mean \pm standard error of mean and as percentages (\%). One-way analysis of variance (post-hoc least significant difference test) was used for the statistical analysis. Probability levels of less than 0.05 ( $p<0.05)$ were considered significant.

\section{RESULTS}

In order to investigate the hypoglycemic activities of extracts of the aerial parts and roots of $A$. persica on alloxan-induced diabetes in mice blood glucose levels were measured before and 1,2 , and $4 \mathrm{~h}$ after treatment. Table displays the effect of the A. persica extracts on blood sugar levels. The current study's 
Table. Blood sugar levels of mice with alloxan-induced diabetes

\begin{tabular}{|c|c|c|c|c|}
\hline \multirow{3}{*}{ Groups } & \multicolumn{4}{|c|}{ Blood sugar levels (mg/dL) } \\
\hline & \multirow{2}{*}{$\begin{array}{l}\text { Before } \\
\text { treatment } \\
\text { with } \\
\text { Alchemilla } \\
\text { persica }\end{array}$} & \multicolumn{3}{|c|}{ After treatment with Alchemilla persica } \\
\hline & & $1 \mathrm{~h}(0-1)$ & $2 \mathrm{~h}(0-2)$ & $4 h(0-4)$ \\
\hline Control (ISS) & $470.00 \pm 23.62$ & $471.00 \pm 13.78(0.74 \pm 3.99)$ & $493.80 \pm 15.55(5.54 \pm 3.73)$ & $494.20 \pm 27.32(4.97 \pm 2.18)$ \\
\hline Alchemilla persica (AE) 100 mg/kg & $306.67 \pm 36.13$ & $501.67 \pm 27.97(70.97 \pm 15.01)^{\star}$ & $484.67 \pm 22.12(67.15 \pm 17.39)^{*}$ & $387.66 \pm 20.77(36.35 \pm 17.91)$ \\
\hline Alchemilla persica (AE) 200 mg/kg & $297.40 \pm 38.09$ & $410.00 \pm 25.37(42.81 \pm 10.85)^{\star}$ & $354.20 \pm 33.90(22.50 \pm 12.27)$ & $290.60 \pm 59.97(1.36 \pm 26.06)$ \\
\hline Alchemilla persica (R) 100 mg/kg & $337.00 \pm 27.28$ & $379.83 \pm 52.56(14.45 \pm 15.87)$ & $425.33 \pm 52.26(29.80 \pm 17.04)$ & $355.83 \pm 61.67(8.87 \pm 18.78)$ \\
\hline Alchemilla persica (R) 200 mg/kg & $405.17 \pm 24.40$ & $445.00 \pm 44.83(9.01 \pm 7.30)$ & $427.83 \pm 50.04(4.64 \pm 9.13)$ & $305.80 \pm 63.67(-23.73 \pm 13.49)$ \\
\hline
\end{tabular}

Mean \pm standard error of mean; Results of post-hoc LSD test; *: Comparison with SF group ( $p<0.05)$

AE: Aerial parts, R: Roots, LSD: Least significant difference, ISS: Isotonic saline solution

results revealed that none of the extracts induced significant reductions in the levels of blood sugar ( $p>0.05$ ). On the other hand, notable increases in blood glucose levels were observed $1 \mathrm{~h}$ and $2 \mathrm{~h}$ after treatment with the aerial parts of $A$. perisca at $100 \mathrm{mg} / \mathrm{kg}$ dosage and $1 \mathrm{~h}$ after treatment with $200 \mathrm{mg} / \mathrm{kg}$ dosage. A decrease in blood glucose level was detected only with treatment of $A$. persica roots at $200 \mathrm{mg} / \mathrm{kg}$ dosage $4 \mathrm{~h}$ after treatment. However, the results were not significant.

\section{DISCUSSION}

In Turkish folk medicine, the use of Alchemilla compactilis Juz., Alchemilla speciosa Buser, and other Alchemilla species for the treatment of diabetes is recorded. ${ }^{20,21}$ The present study did not confirm the usage of $A$. persica in folk medicine for the treatment of diabetes. A previous study related to the hypoglycemic effect of Alchemilla xanthochlora (A. vulgaris) also reported that decoction of the leaves was not active on streptozotocininduced diabetic mice. ${ }^{8}$ The aerial parts and roots of Acanthus mollis were also tested for their antidiabetic activities and results similar to those for $A$. persica were obtained. ${ }^{26}$ All study results indicated that the Alchemilla species $A$. mollis, $A$. vulgaris, and $A$. persica had no lowering effect on blood glucose levels. In contrast, the aerial parts of $A$. mollis and $A$. persica increased blood glucose levels at $100 \mathrm{mg} / \mathrm{kg}$ and $200 \mathrm{mg} / \mathrm{kg}$ dosages $4 \mathrm{~h}$ after treatment.

\section{CONCLUSIONS}

Based on the current study results, the aerial parts and roots of $A$. persica are not useful for decreasing blood sugar levels in short-term treatment. Furthermore, $A$. persica is not suitable in phytotherapy for other medicinal purposes in diabetic patients.

Conflict of Interest: No conflict of interest was declared by the authors.

\section{REFERENCES}

1. Hayırlıoglu-Ayaz S, Inceer H. Three new Alchemilla L. (Rosaceae) records from Turkey. Pak J Bot. 2009;41:2093-2096.
2. Faghir MB, Attar F, Shavvon RS, Mehrmanesh A. Pollen morphology of the genus Alchemilla L. (Rosaceae) in Iran. Turk J Bot. 2015;39:267-279.

3. Davis PH. Flora of Turkey and the East Aegean Islands. Edinburgh University Press; 1982:99.

4. PDR for Herbal Medicines. (2nd ed.). Montvale, NJ; Thomson Medical Economics; 2000.

5. Said O, Khalil K, Fulder S, Azaizeh H. Ethnopharmacological survey of medicinal herbs in Israel, the Golan Heights and the West Bank region. J Ethnopharmacol. 2002;83:251-265.

6. Tasic S. Ethnobotany in SEE-WB countries; Traditional Uses of Indigenous Plants. Lek Sirov. 2012;32:71-81.

7. Blumenthal M, Werner RB. The Complete German Commission E Monographs: Therapeutic Guide to Herbal Medicines. (1st ed). Austin, Texas; American Botanical Council, Lippincott Williams \& Wilkins; 1998:158.

8. Mills MS, Hutchins R. European Scientefic Cooperative on Phytotherapy (ESCOP) Monographs Online Series, Alchemilla herba-Alchemilla/Lady's Mantle. United Kingdom; ESCOP Notaries House; 2013.

9. Saraç DU, Ozkan ZC, Akbulut S. Ethnobotanic features of Rize/Turkey province. Biological Diversity and Conservation. 2013;6:57-66.

10. Kaval I, Behçet L, Cakilcioglu U. Ethnobotanical study on medicinal plants in Geçitli and its surrounding (Hakkari-Turkey). J Ethnopharmacol. 2014;155:171-184.

11. Güzel Y, Güzelșemme M, Miski M. Ethnobotany of medicinal plants used in Antakya: A multicultural district in Hatay Province of Turkey. J Ethnopharmacol. 2015;174:118-152.

12. Mükemre M, Behçet L, Çakılcıoğlu U. Ethnobotanical study on medicinal plants in villages of Çatak (Van-Turkey). J Ethnopharmacol. 2015;166:361374.

13. Baytop T. Türkiye'de Bitkiler ile Tedavi. İstanbul; Nobel Tıp Kitabevleri Ltd Şti; 1999.

14. Altundağ $\mathrm{E}$, Ozturk M. Ethnomedicinal studies on the plant resources of east Anatolia, Turkey. Procedia Social and Behavioral Sciences. 2011;19:756-777.

15. Akbulut S, Bayramoğlu MM. The trade and use of some medical and aromatic herbs in Turkey. Ethno Med. 2013;7:67-77. 
16. Polat R, Satı F, Cakılcıoğlu U. Medicinal plants and their use properties of sold market in Bingöl (Turkey) district. Biological Diversity and Conservation. 2011;4:25-35.

17. Sağıroğlu M, Arslanturk A, Akdemir ZK, Turna M. An ethnobotanical survey from Hayrat (Trabzon) and Kalkandere (Rize/Turkey). Biological Diversity and Conservation. 2012;5:31-43.

18. Kalankan G, Ozkan ZC, Akbulut S. Medicinal and aromatic wild plants and traditional usage of them in Mount Ida (Balıkesir/Turkey). JABS. 2015;9:25-33.

19. Polat R, Çakılcıoğlu U, Kaltalıoğlu K, Ulusan MD, Türkmen Z. An ethnobotanical study on medicinal plants in Espiye and its surrounding (Giresun-Turkey). J Ethnopharmacol. 2015;163:1-11.

20. Akbulut S, Bayramoğlu MM. Reflections of socio-economic and demographic structure of urban and rural on the use of medicinal and aromatic plants: the sample of Trabzon Province. Ethno Med. 2014;8:89100.

21. Akbulut S, Ozkan ZC. Traditional usage of some wild plants in Trabzon region (Turkey). Kastamonu Univ. Journal of Forestry Faculty. 2014;14:135-145.
22. Ergene B, Bahadır Acıkara Ö, Bakar F, Saltan G, Nebioğlu S. Antioxidant Activity and Phytochemical Analysis of Alchemilla persica Rothm. J Fac Pharm. 2010;39:145-154.

23. Küpeli Akkol E, Demirel MA, Bahadır Acıkara Ö, Süntar I, Ergene B, Ilhan M, Ozbilgin S, Saltan G, Keleş H, Tekin M. Phytochemical analyses and effects of Alchemilla mollis (Buser) Rothm. and Alchemilla persica Rothm. in rat endometriosis model. Arch Gynecol Obstet. 2015;292:619628.

24. Ergene Öz B, Ilhan M, Özbilgin S, Küpeli Akkol E, Bahadır Acıkara Ö, Saltan G, Keleş H, Süntar I. Effects of Alchemilla mollis and Alchemilla persica on the wound healing process. Bangladesh Journal of Pharmacology. 2016;11:577-584.

25. Heshmati Afshar F, Maggi F, Ferrari S, Peron G, Dall'Acqua S. Secondary Metabolites of Alchemilla persica Growing in Iran (East Azarbaijan). Natural Product Communications. 2015;4:1-10.

26. Özbek H, Bahadır Acıkara Ö, Keskin I, Kırmızı NI, Özbilgin S, Ergene Öz B, Kurtul E, Özrenk BC, Tekin M, Saltan G. Evaluation of hepatoprotective and antidiabetic activity of Alchemilla mollis. Biomed Pharmacother. 2017;86:172-176. 